\title{
Performance of pearl millet under agri-horti system as influenced by sowing methods and integrated nutrient management in Vindhyan region of Uttar Pradesh, India
}

\author{
S. K. Verma ${ }^{1}$, Ugrasen $\operatorname{Yadav}^{1}$, Sushil Kumar ${ }^{1 \& 2^{*}}$ and Kairovin Lakra ${ }^{3}$ \\ ${ }^{1}$ Department of Agronomy, Institute of Agricultural Sciences, Banaras Hindu University, Varanasi-221005 (Uttar \\ Pradesh), INDIA \\ ${ }^{2}$ ICAR-Central Arid Zone Research Institute, Regional Research Station, Kukma -370105 Bhuj (Gujarat), INDIA \\ ${ }^{3}$ Chandra Sekhar Azad University of Agriculture and Technology, Kanpur- 208002 (Uttar Pradesh), INDIA \\ *Corresponding author. E-mail:sushilangrau@gmail.com \\ Received: November 11, 2017; Revised received: December 12, 2017; Accepted: February 25, 2018
}

\begin{abstract}
An experiment involving three sowing methods and four integrated nutrient management practices was undertaken at Rajeev Gandhi South Campus, Banaras Hindu University in factorial randomized complete block design with three replications. The aim of the study was to assess the effects of sowing methods and integrated nutrients management practices on performance of pearl millet under agri-horti system. The sowing methods and integrated nutrient management practices significantly $(P=0.05)$ influenced performance of pearl millet. Adoption of ridge and furrow sowing method recorded higher growth [plant height $(147.7 \mathrm{~cm})$, dry weight $(72.7 \mathrm{~g})$, and number of tillers plant $^{-1}(2.0)$ ], yield attributes [effective tillers hill ${ }^{-1}(1.77)$, panicle length $(17.9 \mathrm{~cm})$, grains panicle ${ }^{-1}(1508.3)$, grains weight panicle ${ }^{-1}(13.9)$, and test weight $(9.23 \mathrm{~g})$ ], yields [ grain yield $\left(1412 \mathrm{~kg} \mathrm{ha}^{-1}\right)$, and stover yield (3972 kg $\left.\mathrm{ha}^{-1}\right)$ ], and economics [net returns (Rs. $36371 \mathrm{ha}^{-1}$ ), and B:C ratio (1.79) than broadcasting and raised bed. Application of $50 \%$ recommended dose of fertilizer $+50 \%$ poultry manure resulted higher growth [plant height $(151.9 \mathrm{~cm})$, dry weight $(79.7 \mathrm{~g})$, and number of tillers plant ${ }^{-1}(2.22)$ ], yield attributes[effective tillers hill ${ }^{-1}(2.0)$, panicle length (18.8 $\mathrm{cm})$, grains panicle ${ }^{-1}(1615.6)$, grains weight panicle ${ }^{-1}(14.5)$, and test weight $(9.76 \mathrm{~g})$ ], yields [ grain yield (1552 kg $\left.\mathrm{ha}^{-1}\right)$, and stover yield $\left(4360 \mathrm{~kg} \mathrm{ha}^{-1}\right)$ ] and economics [net returns (Rs. $38227 \mathrm{ha}^{-1}$ ), and B:C ratio (1.77) than remaining integrated nutrient management practices. The combination of ridge and furrow and $50 \%$ recommended dose of fertilizer $+50 \%$ poultry manure was adjudged to be better for pearl millet performance.
\end{abstract}

Keywords: Agri-horti system, Integrated nutrient management, Pearl millet, Rainfed, Sowing methods

\section{INTRODUCTION}

Pearl millet (Pennisetum glaucum L.)crop having multiple uses as food, feed, fodder and fuelis considered the sixth most important cereal crop after wheat, rice, maize, sorghum and barley (Singh et al., 2003). The crop is grown on an area of 31 million hectare ( $\mathrm{M} \mathrm{ha}$ ) in the world (ICRISAT, 2016), while in India, it is grown on an area of about $6.98 \mathrm{M}$ hawith 8.06 million tonnes (Mt) production and $1154 \mathrm{~kg} \mathrm{ha}^{-1}$ productivity, respectively (GOI, 2016).Being highly drought resistant crop, itis widely cultivated in rainfed areas of the country either as sole or as intercrop in agroforesty systems. Despite, poor management and unfavourable growing conditions viz. limited soil moisture supply and poor fertility status in rainfed areas, pearl milletthrives well but finally results in producing low yield. Adoption of improved agronomic practices such as sowing methods and integrated nutrient management (INM) not only enhance growth, yield and economics of crop (Parihar et al., 2010; Sharma et al.,
2015; Kumar et al., 2016) but also help in conserving precious natural resources (Bana et al., 2016), improving soil fertility, soil structure, water holding capacity and root proliferation (Bana, 2006), besides improving ecosystem health. Since, the information on sowing methods and INM in pearl millet under guava based agri-horti systemin rainfed Vindhyan region of Uttar Pradesh is meager, the present study attempted to assess the effects of sowing methods and INM on the growth, yield attributes, yield and economics of pearl millet grown as inter crop under eight year old guava based agri-horti system in rainfed Vindhyan region of Uttar Pradesh, India.

\section{MATERIALS AND METHODS}

A field experiment was undertakenat Rajeev Gandhi South Campus, Banaras Hindu University, located at Barkachchha in Mirzapur district of Uttar Pradesh, India (Latitude: $25^{\circ} 10^{\prime}$; Longitude: $82^{\circ} 37^{\prime}$ and Altitude: $427 \mathrm{~m}$ above the mean sea level) during the $\mathrm{kha}$ - 
rifseason of 2013-14. The climate of the study area is basically semi-arid to sub-humid nature. It recorded $746.11 \mathrm{~mm}$ rainfall during the cropping period. The maximum and minimum mean temperature was measured as $35.44^{\circ} \mathrm{C}$ and $25.67^{\circ} \mathrm{C}$, respectively. The soil was sandy clay loam in texture, acidic in nature $(\mathrm{pH}$ 5.9)and had low available $\mathrm{N}\left(176.4 \mathrm{~kg} \mathrm{ha}^{-1}\right)$, medium available P (12.15 $\left.\mathrm{kg} \mathrm{ha}^{-1}\right)$ and available $\mathrm{K}(186.5 \mathrm{~kg}$ $\left.\mathrm{ha}^{-1}\right)$. The bulk and particle densityfrom $0-30 \mathrm{~cm}$ soil depth was recorded 1.53 and $2.48 \mathrm{Mg} \mathrm{m}^{-3}$, respectively (Yadav, 2014). The experiment was laid-out in factorial randomized complete block designwith three replications. The treatments consisted of three sowing methods viz. broadcasting, ridge and furrow and raised bed and four INM practicesviz. 50\% RDF (recommended dose of fertilizer) $+50 \%$ FYM (farm yard manure), $50 \%$ RDF $+50 \%$ poultry manure, $50 \%$ $\mathrm{RDF}+50 \%$ vermicompost and control. The fieldwas prepared according to local practices being followed by farmers for pearl millet production. The hybrid variety 'Kaveri Super Boss' was sownas pertreatments specification on August 8, 2013 with the help of hand operated kudal at spacing of $45 \times 15 \mathrm{~cm}$ with seed rate @ $4 \mathrm{~kg} \mathrm{ha}^{-1}$ in $4.5 \times 3 \mathrm{~m}^{2}$ gross plot size under 8 years old guava based agri-horti system. The nutrient requirement, as per treatments, was supplied from urea, single super phosphate, murate of potash, FYM, poultry manure and vermicompost, respectively. All the nutrient sources were applied at time ofsowing. The crop was raised by following standard agronomic procedures and need based cultural operations were also adopted to keep the crop in vigorous condition. The crop was fully raised as rainfed crop. The 10 plants in each plot were randomly selected and tagged and were subsequently used for recording growth parameters ( at 30, 60 DAS and at harvest) and yield attributes by adopting standard procedures. The crop from net plots after discarding border area plants was harvested and used for recording grain, straw and biological yield. The harvest index was calculated using following equation

$$
\text { Harvestindex }=\frac{\text { Economicyield (kgha-1) }}{\text { Biologicalyield }\left(\mathrm{kgha} \alpha-^{1}\right)} X 100
$$

To workout the economics of the treatments, the cost of inputs involved in raising crop and output price were used as per local market and accordingly cost of cultivation, gross returns, net returns and $\mathrm{B}: \mathrm{C}$ ratio were calculated. The data recorded as part of study were analysed as per procedure described by Gomez and Gomez (1984).

\section{RESULTS AND DISCUSSION}

Growth and yield: The growth and yield data are presented in table 1. It was evident fromthe results that the sowing methods and INM significantly $(\mathrm{P}=0.05)$ influenced all the growth parameters and yields. Among

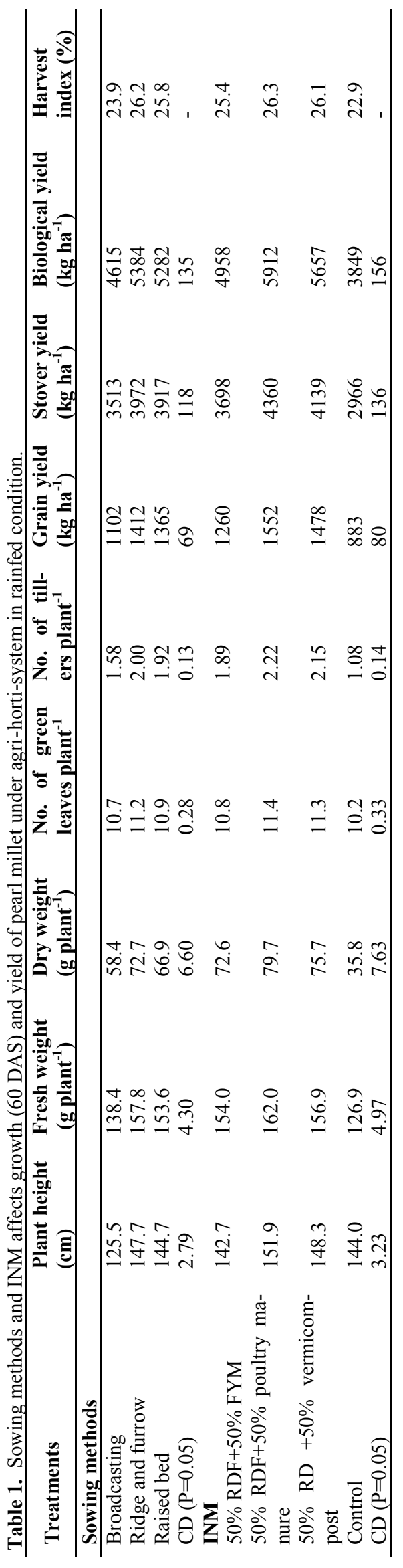


Table 2. Interaction effects of sowing methods and INM on grain, stover and biological yield of pearl millet under agri-hortisystem in rainfed condition.

\begin{tabular}{|c|c|c|c|c|c|}
\hline Treatments & & INM & & & \\
\hline Sowing methods & $\begin{array}{l}\mathbf{5 0 \%} \text { RDF+50\% } \\
\text { FYM }\end{array}$ & $\begin{array}{l}50 \% \text { RDF }+50 \% \text { poul- } \\
\text { try manure }\end{array}$ & $\begin{array}{l}\mathbf{5 0 \%} \text { RDF+50\% ver- } \\
\text { micompost }\end{array}$ & Control & Mean \\
\hline \multicolumn{6}{|c|}{ Grain yield $\left(\mathrm{kg} \mathrm{ha}^{-1}\right)$} \\
\hline Broadcasting & 1009 & 1332 & 1248 & 820 & 1102 \\
\hline Ridge\& furrow & 1432 & 1691 & 1594 & 932 & 1412 \\
\hline Raised bed & 1338 & 1633 & 1592 & 898 & 1365 \\
\hline Mean & 1260 & 1552 & 1478 & 883 & \\
\hline $\mathrm{CD}(\mathrm{P}=0.05)$ & 139 & & & & \\
\hline \multicolumn{6}{|c|}{ Stover yield $\left(\mathrm{kg} \mathrm{ha}^{-1}\right)$} \\
\hline Broadcasting & 3312 & 4075 & 3700 & 2967 & 3513 \\
\hline Ridge\& furrow & 3931 & 4519 & 4423 & 3014 & 3972 \\
\hline Raised bed & 3850 & 4488 & 4414 & 2917 & 3917 \\
\hline Mean & 3698 & 4360 & 4179 & 2966 & \\
\hline $\mathrm{CD}(\mathrm{P}=0.05)$ & 236 & & & & \\
\hline \multicolumn{6}{|c|}{ Biological yield $\left(\mathrm{kg} \mathrm{ha}^{-1}\right)$} \\
\hline Broadcasting & 4321 & 5406 & 4948 & 3786 & 4615 \\
\hline Ridge \&furrow & 5364 & 6209 & 6017 & 3946 & 5384 \\
\hline Raised bed & 5189 & 6121 & 6006 & 3814 & 5282 \\
\hline Mean & 4958 & 5912 & 5657 & 3849 & \\
\hline $\mathrm{CD}(\mathrm{P}=0.05)$ & 270 & & & & \\
\hline
\end{tabular}

Table 3. Sowing methods and INM affects yield attributes of pearl millet under agri-horti-system in rainfed condition.

\begin{tabular}{|c|c|c|c|c|c|c|}
\hline Treatments & $\begin{array}{l}\text { Effective } \\
\text { tillers hill }^{-1}\end{array}$ & $\begin{array}{l}\text { Panicle } \\
\text { length }(\mathrm{cm})\end{array}$ & $\begin{array}{l}\text { Panicle } \\
\text { girth }(\mathrm{cm})\end{array}$ & $\begin{array}{l}\text { Grains } \\
\text { panicle }^{-1}\end{array}$ & $\begin{array}{l}\text { Grain weight } \\
\text { panicle }^{-1} \text { (g) }\end{array}$ & $\begin{array}{l}\text { Test weight } \\
\text { (g) }\end{array}$ \\
\hline \multicolumn{7}{|l|}{ Sowing methods } \\
\hline Broadcasting & 1.42 & 13.8 & 5.37 & 1340.8 & 12.3 & 7.46 \\
\hline Ridge and furrow & 1.77 & 17.9 & 6.12 & 1508.3 & 13.9 & 9.23 \\
\hline Raised bed & 1.64 & 17.2 & 5.84 & 1453.3 & 13.4 & 8.67 \\
\hline $\mathrm{CD}(\mathrm{P}=0.05)$ & 0.20 & 1.55 & 0.30 & 62.2 & 0.74 & 0.54 \\
\hline \multicolumn{7}{|l|}{ INM } \\
\hline $50 \% \mathrm{RDF}+50 \% \mathrm{FYM}$ & 1.65 & 16.0 & 5.99 & 1427.8 & 12.8 & 8.87 \\
\hline $50 \% \mathrm{RDF}+50 \%$ poultry manure & 2.00 & 18.8 & 6.19 & 1615.6 & 14.5 & 9.76 \\
\hline $50 \% \mathrm{RDF}+50 \%$ vermicompost & 1.87 & 17.6 & 6.05 & 1543.3 & 13.4 & 9.42 \\
\hline Control & 0.91 & 12.8 & 4.88 & 1016.7 & 7.1 & 5.76 \\
\hline $\mathrm{CD}(\mathrm{P}=0.05)$ & 0.23 & 1.79 & 0.35 & 71.8 & 0.86 & 0.86 \\
\hline
\end{tabular}

Table 4.Sowing methods and INM affects economics of pearl millet under agri-horti-system in rainfed condition.

\begin{tabular}{|c|c|c|c|c|}
\hline Treatments & $\begin{array}{l}\text { Cost of cultivation } \\
\left(\mathrm{Rs} \mathrm{ha}^{-1}\right)\end{array}$ & $\begin{array}{ll}\begin{array}{l}\text { Gross } \\
\left(\text { Rs ha }^{-1}\right)\end{array} & \text { returns } \\
\end{array}$ & $\begin{array}{l}\text { Net returns } \\
\left(\text { Rs ha }^{-1}\right)\end{array}$ & B:C ratio \\
\hline \multicolumn{5}{|l|}{ Sowing methods } \\
\hline Broadcasting & 19802 & 51800 & 31997 & 1.68 \\
\hline Ridge and furrow & 20772 & 57144 & 36371 & 1.79 \\
\hline Raised bed & 21160 & 56352 & 35192 & 1.70 \\
\hline $\mathrm{CD}(\mathrm{P}=0.05)$ & 2573 & 1213 & 1267 & 0.05 \\
\hline \multicolumn{5}{|l|}{ INM } \\
\hline $50 \% \mathrm{RDF}+50 \% \mathrm{FYM}$ & 21540 & 54445 & 32905 & 1.53 \\
\hline $50 \% \mathrm{RDF}+50 \%$ poultry manure & 21588 & 59816 & 38227 & 1.77 \\
\hline $50 \% \mathrm{RDF}+50 \%$ vermicompost & 24108 & 58437 & 34328 & 1.42 \\
\hline Control & 15076 & 47697 & 32621 & 2.17 \\
\hline $\mathrm{CD}(\mathrm{P}=0.05)$ & 2228 & 1051 & 1189 & 0.06 \\
\hline
\end{tabular}

sowing methods, ridge and furrow resulted higher growth parameters and yields consisting of grain, stover and biological yield followed by raised bed and broadcasting, respectively. Adoption ofridge and furrowsowing method increased 2 and $19.2 \%$ plant height, 2.7 and 19.4\% fresh weight and 8.6 and $14.3 \%$ dry weight over raised bed and broadcasting, respectively. The no. of green leaves and tillers plant ${ }^{-1}$ across sowing methods ranges between 10.7-11.2 and 1.58-2, respectively. Concerning grain, stover and biological yield, ridge and furrow sowing method further adjudged better over rest of the sowing methods and recorded almost 28, 13 and 16\% more grain, stover and biological yield, respectively than broadcasting. Our results are in agreement with the research findings of Kantwa et al. (2006) and Parihar et al. (2010).The har- 
vest index varied between $23.9-26.2 \%$ across the sowing methods but higher harvest index $(26.2 \%)$ was recorded with ridge and furrow method. Among INM practices, the application of $50 \% \mathrm{RDF}+50 \%$ poultry manure observed significantly higher growth and yield. Whereas, application of 50\% RDF $+50 \%$ FYM observed lowest growth and yield among nutrient management practices but performed fairy better than control. Being superiorINM practice, $50 \% \mathrm{RDF}+50 \%$ poultry manure increased plant height $(5 \%)$, fresh weight $(27.6 \%)$ and dry weight $(122.6 \%)$ over control. The maximum and minimum grain, stover and biological yields were recorded with $50 \% \mathrm{RDF}+50 \%$ poultry manure and control, respectively butamong INM practices, poultry based practice recorded significantly higher grain, stover and biological followed by $50 \%$ $\mathrm{RDF}+50 \%$ vermicompost and 50\% RDF $+50 \%$ FYM, respectively. Poultry based INM practice increased grain, stover and biological yield in the tune of 75,46 and $53 \%$ over control, respectively. INMalso influenced harvest index, which ranges from 22.9$26.3 \%$ across the treatments. The highest harvest index $(26.3 \%)$ was recorded with $50 \%$ RDF $+50 \%$ poultry manure followed by $50 \% \mathrm{RDF}+50 \%$ vermicompost but lowest harvest index $(22.9 \%)$ was observed with control. It was also observed that the application of $50 \%$ RDF $+50 \%$ poultry manure recorded almost $15 \%$ increase in harvest index over control. These results closely corroborate with the research findings of Parihar et al. (2010) and Bana et al. (2016).Interaction effects of sowing methods and INM was found to be significant $(\mathrm{P}=0.05)$ for grain, stover and biological yield. The combination of ridge and furrow and $50 \%$ RDF $+50 \%$ poultry manure recorded highest grain (1691 kg ha $\mathrm{kg}^{-1}$ ), stover (4519 $\mathrm{kg} \mathrm{ha}^{-1}$ ) and biological yield $\left(6209 \mathrm{~kg} \mathrm{ha}^{-1}\right)$ over rest of the combinations.

Yield attributes: The yield attributes viz. effective tillers hill $^{-1}$, panicle length $(\mathrm{cm})$, and panicle girth, grains panicle ${ }^{-1}$, grain weight panicle ${ }^{-1}(\mathrm{~g})$ and test weight were recorded and presented in table 3 . It was seen from the data that sowing methods and INM significantly $(\mathrm{P}=0.05)$ influenced yield attributes of pearl millet. Among the sowing methods, the highest [panicle length $(17.9 \mathrm{~cm})$, grains weight panicle ${ }^{-1}$ (1508.3) and test weight $(9.23 \mathrm{~g})$ ] and lowest [panicle length $(13.8 \mathrm{~cm})$, grains weight panicle ${ }^{-1}(1340.8)$ and test weight $(7.46 \mathrm{~g})$ yield attributes were observed with ridge and furrow and broadcasting, respectively. However, raised bed observed yield attributes [panicle length $(17.2 \mathrm{~cm})$, grains weight panicle ${ }^{-1}(1453.3)$ and test weight $(8.67 \mathrm{~g})$ ] at par with ridge and furrow but significantly higher than broadcasting. Ridge and furrow method not only increased grains panicle ${ }^{-1}$ $(12.5 \%)$, grain weight panicle ${ }^{-1}(13 \%)$ and test weight (23.7\%) over broadcasting but also significantly increased effective tillers hill ${ }^{-1}$, panicle length, and pani- cle girth in the tune of $24.6,29.7$ and 14\%, respectively. The superiority of ridge and furrow sowing method might be due to proper drainage of excess rainfall water and better moisture conservation (Kantwa et al., 2006: Parihar et al., 2010). With respect to INM practices, the highest yield attributes were recorded with $50 \% \mathrm{RDF}+50 \%$ poultry manure (NPK-1.3, 0.4 and $0.7 \%$, respectively) followed by $50 \% \mathrm{RDF}+50 \%$ vermicompost, $50 \%$ RDF $+50 \%$ FYM and control, respectively. It was observed from the results that maximum increase in yield attributes over control was recorded with $50 \% \mathrm{RDF}+50 \%$ poultry manure followed by $50 \% \mathrm{RDF}+50 \%$ vermicompost and $50 \% \mathrm{RD}+$ $50 \%$ FYM, respectively. Furthermore, poultry based INM recorded significantly $(\mathrm{P}=0.05)$ higher yield attributes than $50 \%$ RDF $+50 \%$ FYM but at par with $50 \% \mathrm{RDF}+50 \%$ vermicompost. Application of organic materials recorded better results over control might be due to balanced supply of major and micro nutrients and increase in water holding capacity of soil. Almost similar research findings have also been reported by Parihar et al. (2010) and Bana et al. (2016).

Economics: The economics data viz. cost of cultivation, gross and net returns and B: $\mathrm{C}$ ratio are presented in table 4. Sowing methods and INM significantly $(\mathrm{P}=0.05)$ influenced pearl millet economics. The highest and lowest gross and net returns and $\mathrm{B}: \mathrm{C}$ ratio among the sowing methods, were recorded withridge and furrow and broadcasting, respectively.Ridge and furrow sowing method recorded significantly higher gross $(10.3 \%)$ and net returns $(13.6 \%)$ and $\mathrm{B}$ : $\mathrm{C}$ ratio $(6.5 \%)$ over broadcasting but performed at par with raised bed. Similar research findings were also reported by Kantwa et al. (2006) and Parihar et al (2010).With respect to INM, the highest gross returns, net returns and $\mathrm{B}: \mathrm{C}$ ratio was recorded with $50 \% \mathrm{RDF}$ $+50 \%$ poultry manure followed by $50 \%$ RDF $+50 \%$ vermicompost, $50 \% \mathrm{RD}+50 \%$ FYM and control, respectively. The results also indicated that theapplication of $50 \%$ RDF $+50 \%$ poultry manure performed significantly better than $50 \% \mathrm{RDF}+50 \% \mathrm{FYM}$ and control but at par with $50 \% \mathrm{RDF}+50 \%$ vermicompost with respect to gross, net returns and $\mathrm{B}: \mathrm{C}$ ratio. Our results corroborate the research findings of Bana et al (2016).

\section{Conclusion}

It is concluded that ridge and furrow sowing method and $50 \% \mathrm{RDF}+50 \%$ poultry manure INM practice were the best for enhancing growth viz. plant height (147.7 and $151.9 \mathrm{~cm}$ ), dry weight $(72.7$ and $79.7 \mathrm{~g}$ ), yield attributes viz. panicle length $(17.9$ and $18.8 \mathrm{~cm})$ and test weight (9.23 and $9.76 \mathrm{~g}$ ), yield grain (1412 and1552 $\mathrm{kg} \mathrm{ha}^{-1}$ ) and biological yield (5384 and 5912 $\mathrm{kg} \mathrm{ha}^{-1}$ ) and economics in terms of net returns (Rs. 36371 and $38227 \mathrm{ha}^{-1}$ ) and $\mathrm{B}: \mathrm{C}$ ratio (1.79 and 1.77) of 
pearl millet grown as intercrop under guava based agrihorti system in rainfed conditions of Vindhyan region of Uttar Pradesh.

\section{REFERENCES}

Agricultural Statistics at a Glance (2016). Directorate of Economics and Statistics, Ministry of Agriculture \& Farmers Welfare, GOI.

Bana, R.S. (2006). Effect of different organic sources of nutrients on pearl millet-wheat cropping system. M.Sc. Thesis, Division of Agronomy, Indian Agricultural research Institute, New Delhi.

Bana, R.S., Pooniya, V., Choudhary, A.K., Rana, K.S. and Tyagi, V.K. (2016). Influence of organic nutrient sources and moisture management on productivity, biofortification and soil health in pearl millet (Pennisetum glaucum) + clusterbean (Cyamopsis tetragonaloba) intercropping system of semi-arid India. Ind. J. Agric. Sci.86(11):1418-25.

Gomez, A.K. and Gomez, A.A. (1984). Statistical procedures for agricultural research(2nd edn.). John Wiley \& Sons.London, UK.

ICRISAT (International Crops Research Institute for the Semiarid Tropics). (2016). Pearl millet. [2016-01-20]. http://exploreit.icrisat.org/page/pearl_millet/680/274 2016

Kantwa, S.R., Ahlawat, I.P.S. and Gangaiah, B. (2006). Performance of sole and intercropped pigeonpea (Cajanus cajan) as influenced by land configuration, post- monsoon irrigation and phosphorus fertilization. Ind. J. Agric. Sci.76(10):635-637.

Kumar, A., Chugh, L., Yadav, D.V., Malik, R.S. and Kumar, L.C.M. (2016). Effect of farmyard manure, organic manure and balanced fertilizers application on the productivity and soil fertility in pearl millet (Pennisetum glaucum)-mustard (Brassica juncea) cropping sequence in sandy loam soil of semi-arid regions. Ind. J. Agric. Sci.86(2):220-226.

Parihar, C.M., Rana, K.S. and Kantwa, S.R. (2010). Nutrient management in pearl millet (Pennisetum glaucum)mustard (Brassica juncea) cropping system as affected by land configuration under limited irrigation. Ind. J. Agron.55(3):191-196.

Sharma, B., Kumar, R., Kumar, P., Meena, S.K. and Singh, R.M. (2015). Effect of Planting Pattern on Productivity and Water Use Efficiency of Pearl Millet in the Indian Semi-Arid Region. J. Ind. Soc. Soil. Sci. 63(3): 259265.

Singh, R., Singh, D.P. and Tyagi, P.K. (2003). Effect of azotobacter, farmyard manure and nitrogen fertilization on productivity of pearl millet hybrids (Pennisetum glaucum) in semi-arid tropical environment. Arch. Agrono. SoilSci.49:21-24.

Yadav, U. (2014). Effect of sowing methods and integrated nutrient management on growth and yield of pearl millet (Pennisetum glaucum L.) under guava based agrihorti system in rainfed condition of Vindhyan region. M.Sc. Thesis, Institute of Agricultural Sciences, BHU, Varanasi. 